\title{
膀胱腫瘍の臨床統計的研究
}

\author{
\begin{tabular}{ccccc} 
& 松 & \multicolumn{1}{c}{ 田 } & 稔 \\
& 多 & 田 & 安 & 温 \\
大阪大学医学部泌㽷器科学教室 & 中 & 野 & 悦 & 次 \\
& 藤 & 岡 & 秀 & 樹 \\
& 高 & 羽 & & 津
\end{tabular}

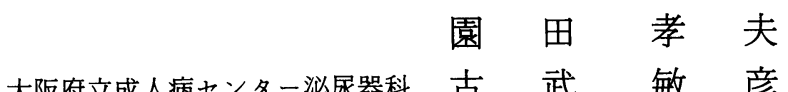 \\ 箕面市立病院泌尿器科 長 船 匡男

\section{CLINICAL STATISTICS OF THE BLADDER TUMOR} \\ Minoru Matsuda, Yasuharu Tada, Etsuji Nakano, Hideki Fujioka, \\ Minato Takaha and Takao Sonoda \\ Department of Urology, Osaka University Hospital \\ (Director: Prof. T. Sonoda) \\ Toshihiko Kotake \\ Department of Urology, The Center for Adult Disease, Osaka \\ (Director: T. Kotake, M.D.) \\ Masao Osafune \\ Department of Urology, Minou City Hospital \\ (Director: M. Osafune, M.D.)
}

From January 1957 to March 1984, 713 patients with bladder tumor were treated at Osaka University Hospital and the clinical statistics of the first occuring tumors were herein described. These 713 cases included 10 of adenocarcinoma of urachal origin, 41 of flat carcinoma, 7 of inverted papilloma 4 of diverticulum tumor and 4 of non-epithelial neoplasms. The results were summarized as followings:

1. Age distribution was from 14 to 88 years old with the average \pm standard deviation of $58.7 \pm$ 12.2. In female patients, the tumors were found at older ages than in male patients. The male to female ratio was 4.1:1.

2. Subjective complaints were gross hematuria, symptomatic or asymptomatic, in $88.8 \%$, pain at micturition in $20.3 \%$, frequency of urination in $22.2 \%$, disturbance of urination in $6.6 \%$ and others in $4.4 \%$.

3. Endoscopically multiple bladder tumors were observed in $42.5 \%$. Small tumors (below $1 \mathrm{~cm}$ in diameter) constituted $8.9 \%$, medium sized ones ( 1 to $3 \mathrm{~cm}$ ) $41.7 \%$ and large mass (more than $3 \mathrm{~cm}$ ) $49.4 \%$. Papillary tumors with stalk were found in $44.0 \%$, papillary sessile tumors in $31.7 \%$, non-papillary with stalk in $2.6 \%$ and non-papillary sessile ones in $21.7 \%$. The main tumors located at lateral wall in $42.9 \%$, trigonal area including ureteral orifice in $27.7 \%$, posterior wall in $17.9 \%$, vault in $6.6 \%$, bladder neck in $3.1 \%$ and anterior wall in $2.8 \%$.

4. Apparent metastasis at distant organs were revealed in 13 cases and lymph node involvements in 31 cases.

5. Histologically $93.6 \%$ of the tumors was transitional cell type. Adenocarcinoma and squamous cell carcinoma constituted $3.2 \%$ and $1.6 \%$, respectively. Others included non-epithelial type and inflmmatory lesions, the latters were certainly misdiagnosed due to inadquate pathological specimens.

6. From comparative study of clinical and pathological stage, it could be said that there was a 
tendency of overstimation at preoperative diagnosis.

7. Between pathological stage and grade of malignancy, there was significant correlation by chisquare test.

8. Correlation of stage or grade of the tumors and chief complaints, size, multiplicity, shape and location was studied by chi-square test. With the progress of the stage or grade, the patients noticed cystitis-like symptomes, the size of the tumors increased, multiple tumors became frequent, and all these findings were statistically significant.

9. The treatments applied to the first tumors were total cystectomy for 173 cases, partial cystectomy, for 148 cases, tumor resection or mucosal denudation by cystotomy for 30 cases, transurethral resection for 259 cases and transurethral coagulation for 34 cases. In 68 cases, the treatments were non-surgical procedures. Irradiation was performed in 58 patients, as a definite treatment for the tumors in 25 cases, as preoperative irradiation in 8 cases, for prophylaxis to intravesical recurrence in 20 cases. The procedures were for the treatment of metastatic lesions in 3 cases and for postoperative prophylaxis of intrapelvic regrowth in 2 cases. Bladder instillation of cytotoxic agents was performed in 83 cases, most of them were to prevent intravesical recurrence. General administration of anti-cancer agents was also applied in 44 cases, for prevention of intravesical recurrence or distant metastasis in most of the cases, but in 12 , the administration was as the main therapeutic modality.

10. The relative survival rates after the first treatments were $75.3 \%, 71.9 \%, 64.7 \%$ at 3,5 and 10 years, respectively. These rates, of couse, depend on the character of the tumors and the treatments. Detailed description of this problem will be given elsewhere.

11. Intravesical recurrence rate after bladder sparing operation was calculated by actuarial method. The cumulative recurrence rates were $50.9 \%$ at 3 years, $61.5 \%$ at 5 years and $73.9 \%$ at 10 years, regardless of the application of intravesical instillation or external irradiation for prophylaxis.

要旨：1957年 1 月より 1984年 3 月の期間に, 大阪大学医学部附属病院泌尿器科を受診した膀胀腫瘍症例 713例の初発時の臨床像を統計的に検討した。

年齢は14歳から88歳, 平均士標準偏差は58.7 12.2 歳. 男女比は $4.1: 1$, 初発時自覚症は, 肉眼的血 尿が88.8\%にみられたが，排尿痛，頻尿，排尿障害も $20.3 \% ， 22.2 \% ， 6.6 \%$ にられた．多発性腫瘍が $42.5 \%$ 占め, 大きさでは $1 \mathrm{~cm}$ 以下のもの $8.9 \%, 1$ 1 $\mathrm{cm}$ のもの $41.7 \%, 3 \mathrm{~cm}$ 以上 $49.4 \%$ の分布を示し た。腫瘍形態は乳頭状有茎性が $44.0 \%$ と最も多く，次いで乳頭状広基性 (31.7\%), 非乳頭状広基性 (21.7\%) の順であった。発生部位は側壁 (42.9\%)，三角部 (26.7\%)，後壁 (17.9\%) が多く他はいず れも $10 \%$ 以下であった，組織学的には，移行上皮性腫瘍が $93.6 \%$ 占め，他は非常に低頻度である，術 前診断ではやや過大評価の傾向があったが，病理学的浸潤度と悪性度には有意の相関が認められ，また 浸潤度または悪性度と症状，腫瘍の性状との相関も検討した。治療内容についても，非手術的処置を含 め, 実際症例数を示した. 初回治療後の全例の相対生存率は, 3 年, 5 年, 10 年それぞれ $75.3 \%, 71.9 \%$, $64.7 \%$ あるあが，腫瘍の性状と治療法別に今後検討をすすめる. 膀胼保存処置後の腔内再発も生命表法 に準じ算出したが，再発予防処置を無視すると，累積再発率は 3 年 $50.9 \% ， 5$ 年 $61.5 \%, 10$ 年 $73.9 \%$ で あり, 特に TUC 後の再発が多くみられた。

\section{はじめに}

本邦における膀胀腫瘍は最近の疫学的報告によれ ば，人口訂正死亡率でみる限り，一時の増加傾向から 横ばいないし特に女性では多少の減少傾向にあるとも 言われている11. しかしながら，65歳以上の人が10\%を 占める高齢化社会の到来とともに, 症例の実数は増加 していると考学られ, やはり泌尿器科領域で最も多く みられる重要な腫痬であることにかわりはない。
1980年, 日本泌尿器科学会, 日本病理学会の共編に よる膀胖癌取扱い規約 ${ }^{2)}$ (以下規約と略）が刊行され， またこれに基づく全国的規模の症例登録がなされつつ あり, 膀胼腫瘍の臨床統計の成果はいずれ明らかにさ れるであろう。

さて著者もこの登録に参加しているが，周知のごと く膀脂腫瘍症例は腫瘍の性状および治療法の多様性の ため, 長い時間的経過のなかに様々な出来事をもった 
一つの独立した history の感さえあり, 最終的な臨床 統計の成果が明らかになるまでにはな打数年を要する であろら。

この時期にあたり, 昭和32年以降, 多少の迂余曲折 はありつつも，ほぼ一貫した方針で膀脂腫瘍の治療に あたってきた大阪大学医学部附属病院泌尿器科 (以下 当科と略す）の臨床統計を示すことは決して無意味な ことではないと考觉る。な扔本邦では既に同様の研究 報告が多数なされているが, 単一施設での症例数とし ては最も多いものと思われる. 従って統計的数值の信 頼性にも多少の向上があって然るべきと考克, 各症例 の病歴は, 当科での診療内容にとどまらず, 受診前, 受診後の動向も出来る丈明らかにする様努力した. ま た分析するべき項目は多岐に亘るが，本稿は腫瘍初発 時の症例の臨床像, 病理所見拈よび用いられた治療法 とその成績につき概観的にまとめたものである。

\section{対象症例と検討方法}

昭和 32 年 1 月より昭和 59 年 3 月までに当科を受診し た膀胱腫瘍症例713例を対象とした。腎血尿管腫瘍に併 発又は続発した腫瘍は除外し，また隣接蔵器よりの浸 潤性腫瘍も同様とした。しかし, 膀腃腫瘍の中で特異 なカテゴリーかと思われる尿膜管由来腫瘍や非上皮性 腫瘍は本報告のなかに含まれている。

検討方法は, 各症例の病歴, 腫瘍の性状, 処置内容, 病理組織学的診断, 以後の経過などにつき規約に出来 るだけ従って分類, マイクロコンピューターはNEC PC8801とその周辺機器を用い, 統計用プログラムは東 京大学コンピューター医療研究会により作成された $\mathrm{STAX}^{3)}$ 使用, 統計用ファイルは 1 回の腫瘍ごとに 128 ベイトを使用して1レコードを作成, 性別, 腫瘍の 性状など49項目につき入力して分析検討したものであ る.

（1）年齢と性別

713例中 618 例は腫瘍初発とともに当科を受診した が, 他の95例は再発性腫瘍を主とするものであり, 初 発時年齢は病歴よりこれを明らかにしたものである.

最低14歳, 最高88歳に亘り, 平均土標準偏差は $58.7 \pm$ 12.2歳となる. 各年代毎の分布は Fig. 1に示したが, 60 歳台が最多で $33.9 \%$ を占め, 次いで50歳台 $25.1 \%$, 70 歳台 $17.8 \%$ の順である. 全例中 50 歳以上の占める割 合は $78.1 \%$ となる。

これらを男女別にみると, 性比は男：女=4.1：1で あり, 各年代毎の分布をみると最多症例は60歳台で男
Fig. 1 膀胀腫瘍初発時年齢

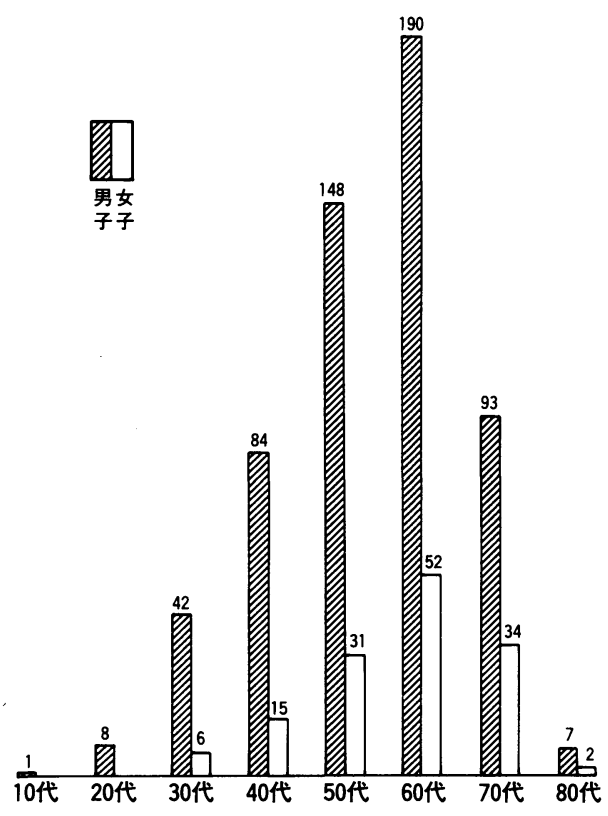

女共通であるが，これに続く年代は男子の50歳台に比 し女子では70歳台が多く, 各年代毎の性比も30歳台よ り70歳台にかけて男女比の近接がみられ，女子では高 齢への分布が多くなる。な技，男子例平均年齢（土標 準偏差）は58.0 012.3 歳，女子例では $61.5 \pm 11.1$ 歳で あり， T-検定により有意の差が認められる $(\mathrm{p}<0.01)$.

(2) 症状

腫瘍初発時の自覚症を, 主症状を 1 つ, 随伴症状を 2つまで入力する方式により分析した。な拈，713例中 31例はこれについての確かな記録が不十分なため, 682 例を対象とした. Table 1に示すように主訴としては 肉眼的血尿が550例 (80.6\%) を占め，ついで頻尿 56 例 (8.2\%), 排尿痛32例 (4.7\%), 排尿障害22例 $(3.2 \%)$ の順となっている。 その他21例はこれ以外の理由であ るが, 偶然の発見や, 顕微鏡的血尿の精査によるもの,

Table 1 膀胱腫瘍初発時の症状

\begin{tabular}{|c|c|c|c|c|}
\hline & 主 訴 & 第 1 随伴症状 & 第 2 随伴症状 & 計 \\
\hline 肉眼的血尿 & 550 & 29 & 21 & 600 \\
\hline 排 尿 痛 & 32 & 95 & 12 & 139 \\
\hline 頻尿 & 56 & 66 & 29 & 151 \\
\hline 排尿 障 害 & 22 & 19 & 4 & 45 \\
\hline その他 & 22 & $\begin{array}{c}6 \\
(467)\end{array}$ & $\begin{array}{c}4 \\
(612)\end{array}$ & 32 \\
\hline 計 (症例数) & 682 & 215 & 70 & \\
\hline
\end{tabular}


職業性膀胱癌が予期される例での尿中細胞診による異 常などが含まれる。随伴する症状の 1 番目としては, 無しの場合が682例中467例 (68.5\%) であり，他の 215 例 $(31.5 \%)$ は何らかの随伴症状を呈し，肉眼的血尿 29 例 (4.3\%)，排尿痛94例(13.8\%)，頻尿66例(9.7\%), 排尿障害19例 (2.8\%)，その他 6 例 $(0.9 \%)$ となって いる.さらに70例は第 2 の随伴をも伴ない, 肉眼的血 尿 21 例 (3.4\%), 排尿痛12例 (2.0\%), 頻尿29例 (4.7\%), 排尿障害 4 例 (0.7\%)，その他 4 例（0.7\%）が集計さ れている。

以上を要約すると, 全例中単一の症状にて発見され たものが $68.5 \%$ であ，31.5\%は第 1 の， らち $10.3 \%$ は第 2 までの随伴する症状を呈していた事になり，ま た随伴症状としての訴えも含めると, 肉眼的血尿は全 例の $88.8 \%$, 排尿痛は $20.3 \%$, 頻尿 $22.2 \%$, 排尿障害 $6.6 \%$ ， その他 $4.4 \%$ とい5自覚症の出現頻度となる.

(3) 内視鏡的所見

\section{a) 腫瘍数}

初発時, 内視鏡的に確認された腫瘍は, 記録の明確 な609例中単発性350例 (57.5\%), 多発性259例 (42.5\%) と単発性腫瘍がやや多い結果であった（Table 2).

b) 大きさ

主腫瘍の大きさで示したが，判明している609例中， 小 $(1 \mathrm{~cm}$ 以下) 54 例 $(8.9 \%)$, 中 $(1 \sim 3 \mathrm{~cm}) 254$ 例 $(41.7 \%)$, 大 (3cm 以上) 301 例 $(49.4 \%)$ と, 約半数 が大きな腫瘍で占められている（Table 2).

c) 形態

茥の有無により，有茥性と広基性に分け，また表面 の性状は乳頭状と非乳頭状に分けたが，ここでは乳頭 状を表面がシダの葉状のものの意味に限定した。なお

Table 2 初発膀胱腫瘍の内視鏡所見

\begin{tabular}{|c|c|c|c|}
\hline 腫 瘍 & & 症例数 & $\%$ \\
\hline 単 & 発 & 350 & $57.4 \%$ \\
\hline 多 & 発 & 259 & $42.5 \%$ \\
\hline \multicolumn{4}{|c|}{ 尰瘍の大きさ（主腫瘍） } \\
\hline \multirow{3}{*}{\multicolumn{2}{|c|}{$\begin{array}{l}\text { 小 }(1 \mathrm{~cm} \text { 以下 }) \\
\text { 中 }(1 \sim 3 \mathrm{~cm}) \\
\text { 大 }(3 \mathrm{~cm} \text { 以上 })\end{array}$}} & 54 & $8.9 \%$ \\
\hline & & 254 & $41.7 \%$ \\
\hline & & 301 & $49.4 \%$ \\
\hline \multicolumn{4}{|c|}{ 腫瘍の性状 } \\
\hline \multicolumn{2}{|c|}{ 乳頭状有茎性 } & 268 & $44.0 \%$ \\
\hline \multicolumn{2}{|c|}{ 乳頭状広基性 } & 193 & $31.7 \%$ \\
\hline \multicolumn{2}{|c|}{ 非乳頭状有茎性 } & 16 & $2.6 \%$ \\
\hline \multicolumn{2}{|c|}{ 非乳頭状広基性 } & 132 & $21.7 \%$ \\
\hline
\end{tabular}

この定義は規約とは異なっている.

結果は判明している609例中, 乳頭状有茎性268例 (44.0\%)，乳頭状広基性193例（31.7\%），非乳頭状有 茎性16例 (2.6\%)，非乳頭状広基性132例（21.7\%）で あり, 乳頭状有茥性腫瘍が約半数近く, 最も多くみら れる形態であった (Table 2).

d) 発生部位

主腫瘍および娘腫瘍のみられた位置につき検討した 結果を Table 3に示す. 検討対象は609例であるが，主 腫瘍と判断されたものが複数個存在した例もあり，腫 瘍数としては637腫瘍である.最も多くみられる部位は 左右を合わせた側壁であり $42.9 \%$ こここに存在する。 左右差は特にない。次いで尿管口周囲を含む三角部で あり $26.7 \%$, 後壁 $17.9 \%$, 項部 $6.6 \%$, 頝部 $3.1 \%$, 前 壁2.8\%の順となっている。多発性259例での娘腫瘍の 分布は338部位に及ぶ.一部位に多発している場合があ り,これが娘腫瘍の総数ではないが, 結果はTable 3 に示した通りである，詳細は省略するが，主腫瘍の分 布と比較すると多少偏位する傾向が减じ, 頝部, 項部, 前壁にも $19.5 \%, 10.7 \% ， 7.4 \%$ が分布する。なおこれ ら腫瘍は肉眼的に確認されたものであり, 術後の顕微 鏡的検索によるものではないことを付記する。

(4) 転移

初発時検査扣よび手術所見を含め, 遠隔蔵器やリン パ節に認められた転移巣につき検討した。

遠隔藏器への転移は不明例が121例あるが, 13例で明 らかに認められ, 579例が通常の術前検査で転移なしと 判断された。 またリンパ節転移は主に手術時の所見に より判断したが，31例に沶いて明らかに認められてい る.しかし他の682例での真の意味でのリンパ節転移の 有無は確認されておらず，このリンパ節転移陽性率は 最低値として差しつかえないものである。

Table 3 膀胖腫瘍の発生部位

\begin{tabular}{|c|c|c|}
\hline 部 位 & 主腫瘍（\%） & 娘腫瘍（\%) \\
\hline 尿 道 & 0 & $1(0.3)$ \\
\hline 頸 部 & $20(3.1)$ & $66(19.5)$ \\
\hline 三角部 & $170(26.7)$ & $65(19.2)$ \\
\hline 後 壁 & $114(17.9)$ & $70(20.7)$ \\
\hline 側 壁 (右) & $144(22.6)$ & 39 (11.5) \\
\hline 側 壁 (左) & $129(20.3)$ & $36(10.7)$ \\
\hline 頂 部 & $42(6.6)$ & $36(10.7)$ \\
\hline 前 壁 & $18(2.8)$ & $25(7.4)$ \\
\hline 計 & 637 & 338 \\
\hline
\end{tabular}


（5）病理組織学的所見

a) 組織型

713例中138例での組織型が不明であり,残る575例で 検討した。

移行上皮性腫瘍は539例（93.7\%）を占め，らち504 例は他の組織型成分をもたないが, 12例は腺癌成分を, 20 例は扁平上皮癌成分を， 3 例は腺癌・扁平上皮癌の いずれの成分をも混在させていた，腺癌は18例 (3.1\%), 扁平上皮癌 9 例 $(1.6 \%)$ ，未分化癌 2 例 (0.3\%)，非上皮性腫瘍 4 例（0.7\%）である。その他 として集計した 3 例はいずれも初発時組織診が cystitis とされたものであるが，以後の経過よりみて， 適当な組織材料が提供されなかったために起った判断 の誤りと考えられ，本質的には腫瘍であったと十分推 定が可能なものである（Table 4).

b) 臨床的, 病理組織学的浸潤度

術前診断 ( T ) , 組織診断 (pT) いずれも不明な95例 を除く618例を検討の対象とした。

術前の浸潤度判定に用いられた手段は各症例で必ず しも同様ではないが, 主に内視鏡, IVP, 膀胱二重造影 が用いられ，血管造影は一時期を除き一般的には施行 されていない.最近の数年間はこれらと共に CT, 経尿

Table 4 病理組織型

\begin{tabular}{|c|c|c|c|}
\hline 主組織型 & 例数 & $(\%)$ & \\
\hline 移行上皮性 (TTC) & 539 例 & ${ }^{93.7}$ ТCC のみ & 504 例 \\
\hline 癌 $(\mathrm{AC}) *$ & 18例 & $3.1 \prod_{\mathrm{TCC}}+\mathrm{AC}$ & 12例 \\
\hline 扁平上皮癌(SCC) & 9例 & $\mathrm{TCC}+\mathrm{SCC}$ & 20例 \\
\hline 未分化癌 & 2例 & ${ }^{\top} \mathrm{TCC}+\mathrm{AC}+\mathrm{SCC}$ & 3例 \\
\hline 非上皮性 & 4例 & 0.3 & \\
\hline 他 (cystitis) & 3例 & 0.3 & \\
\hline 計 & 575例 & & \\
\hline
\end{tabular}

* 10 例の尿膜管由来腫湯を含む

Table 5 臨床的, 病理組織学的浸潤度

\begin{tabular}{c|c|c|r|r|r|r|r|r}
\hline $\mathrm{pT}$ & $\mathrm{T}$ is & $\mathrm{Ta}$ & $\mathrm{T}_{1}$ & $\mathrm{~T}_{2}$ & $\mathrm{~T}_{3}$ & $\mathrm{~T}_{4}$ & 不明 & 計 \\
\hline $\mathrm{pTis}$ & 5 & & 1 & & & & & 6 \\
$\mathrm{pTa}$ & & 15 & 57 & 9 & 3 & & & 84 \\
$\mathrm{pT}_{1}$ & 2 & & 113 & 46 & 14 & & 1 & 176 \\
$\mathrm{pT}_{2}$ & 1 & & 16 & 36 & 24 & 2 & & 79 \\
$\mathrm{pT}_{3}$ & & & 6 & 30 & 44 & 9 & 1 & 90 \\
$\mathrm{pT}_{4}$ & 2 & & & 2 & 7 & 17 & & 28 \\
不明 & 2 & 7 & 77 & 16 & 14 & 39 & & 155 \\
\hline 計 & 12 & 22 & 270 & 139 & 106 & 67 & 2 & 618 \\
\hline
\end{tabular}

道的超音波断層が用いられている。麻酔下双手診は一 部例外を除き施行していない. Table 5にTと pT と の関係を示す. Tの分布は判定不明の 2 例を除き, Tis 12例 (1.9\%), $\mathrm{Ta} \sim \mathrm{T}_{1}$ 292例 (47.4\%), $\mathrm{T}_{2}$ 139例 (22.6\%), $\mathrm{T}_{3} \sim \mathrm{T}_{4}$ 173例 (28.1\%) であった. 各々の Tでの病理組織学的浸潤度は Tis では12例中 2 例で 判定不可能，また残る10例中 5 例 (50\%) が pTis と判 定されたのみで，他は多少の浸潤あるいは前立腺への intraductal spread が認められている. Ta の判定は組 織学的にも比較的よく一致しているが，不明例が多い のはTUC その他の組織標本を得られない治療手段が 採用されたり，切除標本の病理部門への提出方法に問 題があったためである， $\mathrm{T}_{1}$ の群では $\mathrm{Ta}$ 群と同様の理 由で pT 不明例が270例中77例と多いが，これを除く 193例での pT との合致の程度をみると, $\mathrm{pT}_{1}$ と完全に 一致したもの113例 (58.5\%), 実際には pTis, pTa で $\mathrm{T}_{1}$ の判定が過大評価であったもの58例(30.1\%), 逆に 過少評価であったもの 22 例 (11.4\%) とやや過大評価 の傾向が認められた. $\mathrm{T}_{2}$ の判定の妥当性は, $\mathrm{pT}$ 不明の 16例を除く123例中, 完全に一致したもの36例 (29.3\%), 過大評価であったもの55例 (44.7\%), 過少 評価であったもの32例 (26.0\%) と, やはり過大評価 の傾向が認められる. $\mathrm{T}_{3}, \mathrm{~T}_{4}$ の判定で $\mathrm{pT}$ が不明の症 例が173例中53例存在するが, 多くは手術的治療が断念 されている場合である. $\mathrm{T}_{3}$ の判定がなされ $\mathrm{pT}_{3}$ と合致 したものは, 92例中44例(47.8\%)であり, 14例(15.2\%) は過少評価, 41例 (44.6\%) は過大評価であった。 $\mathrm{T}_{4}$ での pT との一致は28例中 17 例 $(60.7 \%)$ であり，他は 当然のことながら過大評価である。

以上より過去の当科での術前浸潤度判定はやや過大 評価の傾向があったものと考えられる。

c）浸潤度と悪性度

713例中浸潤度, 悪性度いづれも不明の147例および 悪性度の不明 9 例を除く557例につき検討した結果を Table 6 に示す。な括 inverted papilloma は一応良性

Table 6 組織学的悪性度と浸潤度

\begin{tabular}{c|c|r|r|r|r|r|r|r}
\hline $\mathrm{pT}$ & $\mathrm{pT}$ is & $\mathrm{pTa}$ & $\mathrm{pT}_{1}$ & $\mathrm{pT}_{2}$ & $\mathrm{pT}_{3}$ & $\mathrm{pT}_{4}$ & 不明 & 計 \\
\hline $\mathrm{G}_{0}$ & & 15 & & & & & 3 & 18 \\
$\mathrm{G}_{1}$ & & 63 & 108 & 28 & 9 & 3 & 64 & 275 \\
$\mathrm{G}_{2}$ & 4 & 6 & 56 & 35 & 40 & 9 & 24 & 174 \\
$\mathrm{G}_{3}$ & 2 & & 10 & 14 & 37 & 15 & 12 & 90 \\
\hline 計 & 6 & 84 & 174 & 77 & 86 & 27 & 103 & 557 \\
\hline
\end{tabular}


Table 7 浸潤度と臨床像

\begin{tabular}{|c|c|c|c|c|c|c|c|c|c|}
\hline \multicolumn{3}{|c|}{\begin{tabular}{|ll} 
臨床像 & $\mathrm{pT}$ \\
\end{tabular}} & pTis & $\mathrm{pTa}$ & $\mathrm{pT}_{1}$ & $\mathrm{pT}_{2}$ & $\mathrm{pT}_{3}$ & $\mathrm{pT}_{4}$ & $\chi^{2}$ 検 定 \\
\hline \multirow[t]{3}{*}{ 主 } & \multicolumn{2}{|c|}{ 訴 } & & & & & & & \multirow{3}{*}{$\mathrm{P}<0.01$} \\
\hline & \multirow{2}{*}{\multicolumn{2}{|c|}{$\begin{array}{l}\text { 肉 眼 的 血 尿 } \\
\text { 頻尿又は排疗痛 }\end{array}$}} & 2 & 74 & 159 & 63 & 61 & 15 & \\
\hline & & & 2 & 3 & 9 & 10 & 23 & 13 & \\
\hline \multirow{4}{*}{\multicolumn{3}{|c|}{ 大きさ }} & & & & & & & \multirow{4}{*}{$\mathrm{P}<0.01$} \\
\hline & & & 2 & 13 & 16 & 1 & 2 & & \\
\hline & & & 3 & 51 & 101 & 26 & 16 & 1 & \\
\hline & & & 1 & 19 & 57 & 52 & 70 & 27 & \\
\hline \multicolumn{3}{|l|}{ 腫瘍数 } & & & & & & & \multirow{3}{*}{$0.01<\mathrm{P}<0.05$} \\
\hline 単 & & 発 & 2 & 50 & 99 & 34 & 52 & 21 & \\
\hline 多 & & 発 & 4 & 33 & 76 & 45 & 36 & 7 & \\
\hline \multicolumn{3}{|l|}{ 形 態 } & & & & & & & \multirow{5}{*}{$\begin{array}{l}\mathrm{P}<0.01 \\
\text { (非乳頭状有茥性 } \\
\text { を除く) }\end{array}$} \\
\hline & 状 & & & 63 & 101 & 24 & 6 & & \\
\hline & 状 & 基 & 1. & 14 & 51 & 33 & 44 & 9 & \\
\hline & 頭 状 & & & 6 & 4 & & 1 & & \\
\hline & 頭状 & & 5 & 1 & 19 & 22 & 37 & 19 & \\
\hline \multicolumn{3}{|l|}{ 部 位 } & & & & & & & \multirow{8}{*}{$\begin{array}{l}\text { 前壁に } \mathrm{pT}_{2} \text { 以上が } \\
\text { 多い }(\mathrm{P}<0.01)\end{array}$} \\
\hline 頸 & & 部 & & 3 & 2 & 1 & 3 & 3 & \\
\hline$\equiv$ & 角 & 部 & 2 & 29 & 44 & 22 & 21 & 8 & \\
\hline 後 & & 壁 & 1 & 16 & 42 & 13 & 13 & 8 & \\
\hline 右 & 側 & 壁 & 2 & 20 & 38 & 19 & 22 & 7 & \\
\hline 左 & 側 & 壁 & 2 & 16 & 37 & 15 & 18 & 11 & \\
\hline 頂 & & 部 & & 1 & 16 & 4 & 12 & 3 & \\
\hline 前 & & 壁 & & & 3 & 3 & 7 & 2 & \\
\hline
\end{tabular}

と考え $\mathrm{G}_{0}$ と分類した ${ }^{4)}$. pTis 6 例の全例が $\mathrm{G}_{2}$ 又は $\mathrm{G}_{3}$ と high gradeであることは当然かと思われる. pTa の84例中63例 (75.0\%)は $\mathrm{G}_{1}$ であり, $\mathrm{G}_{0} 15$ 例 $(17.9 \%)$, $\mathrm{G}_{2} 6$ 例 (7.1\%) の分布を示す. $\mathrm{pT}_{1}$ では $\mathrm{G}_{0}$ はなく, $\mathrm{G}_{1}$ が108例(62.1\%), $\mathrm{G}_{2} 56$ 例(32.2\%), $\mathrm{G}_{3} 10$ 例(5.7\%) と high grade の腫瘍が増加してくる， $\mathrm{pT}_{2}$ では low grade $\left(\mathrm{G}_{1}\right)$ は77例中 28 例 $(36.4 \%)$ となり, $\mathrm{G}_{2}, \mathrm{G}_{3}$ を 合わせた 49 例 $(63.6 \%)$ との逆転がみられる. $\mathrm{pT}_{3}, \mathrm{pT}_{4}$ の群では $\mathrm{G}_{2}, \mathrm{G}_{3}$ の high grade の腫瘍が $89.4 \%$ と大部 分を占める様になる.なおこれら $\mathrm{pT}$ is を除く $\mathrm{pT}$ の各 4 群 (pTa, $\mathrm{pT}_{1}, \mathrm{pT}_{2}, \mathrm{pT}_{3 \sim 4}$ ) と $\mathrm{G}_{0} \sim \mathrm{G}_{3}$ の 4 群の $4 \times$ 4 表による $\chi^{2}$ 検定により $\mathrm{p}<0.01$ の危険率で関連性が あると言える。交た悪性度は判定されているが，pT不 明の症例103例がみられるが，悪性度の分布よりみて $\mathrm{pT}_{1}$ に非常に類似したグループ，すなわち TURを中 心として治療された症例が大部分であり, 前節で述べ た点が $\mathrm{pT}$ 不明の原因になっているものと思われる。

（6）浸潤度と臨床像

腫瘍の浸潤度と主訴, 腫瘍の大きさ, 数, 形態, 発 生部位につき集計したものが Table 7である。
$\mathrm{pT}$ is は例外的なものとし，pTa〜 $\mathrm{pT}_{4}$ との関係をみ ると，主訴については pTの進行と共に膀胱炎症状を 主訴とする場合が多くなり， $2 \times 5$ 表の $\chi^{2}$ 検定にて有 意の関連性が認められる $(\mathrm{p}<0.01)$. 腫瘍の大きさに ついても pT の進行とともに大きな腫瘍がふえ，これ も $3 \times 5$ 表の $\chi^{2}$ 検定により統計学的に有意の関連性 が認められる $(\mathrm{p}<0.01)$. 腫瘍数に関しても $\mathrm{pT}$ の進行 とともに多発例が有意に多くなるが，統計的な危険率 は $0.01<\mathrm{p}<0.05$ とやや高い. 腫腸形態については pTis 招よび症例数の少ない非乳頭状有茎性腫瘍を除 き, $\mathrm{pTa} \sim \mathrm{pT}_{4}$ と乳頭状有茎性，乳頭状広基性，非乳頭 状広基性での $3 \times 5$ 表による $\chi^{2}$ 検定を行ならと $\mathrm{p}<$ $0.01 の$ 危険率での関連性が認められた。発生部位につ いては $\mathrm{pT}_{1}$ 以下と $\mathrm{pT}$ 以上の浸潤度の相違が，特に前 壁と他部位でみられるか否かを検討したが， $x^{2}$ 検定， $\mathrm{p}<0.01$ にて前壁に浸潤度の高い腫瘍が多いとの結論 を得た。

（7）悪性度と臨床像

悪性度と自覚症(主訴), 腫瘍の大きさ, 数, 形態招 よび発生部位の関係をみた結果が Table 8である。 
Table 8 覀性度と臨床像

\begin{tabular}{|c|c|c|c|c|c|c|c|c|}
\hline \multirow{2}{*}{\multicolumn{4}{|c|}{$\begin{array}{l}\text { 臨床像 } \\
\text { 主 訴 } \\
\text { 肉眼 的 血尿 } \\
\text { 頻尿又は排尿痛 }\end{array}$}} & $\mathrm{G}_{0}$ & $\mathrm{G}_{1}$ & $\mathrm{G}_{2}$ & $\mathrm{G}_{3}$ & $\chi^{2}$ 検 定 \\
\hline & & & & $\begin{array}{r}15 \\
1\end{array}$ & $\begin{array}{r}253 \\
6\end{array}$ & $\begin{array}{r}138 \\
23\end{array}$ & $\begin{array}{l}49 \\
34\end{array}$ & $\mathrm{P}<0.01$ \\
\hline \multicolumn{4}{|c|}{ 大きさ } & $\begin{array}{r}10 \\
6\end{array}$ & $\begin{array}{r}24 \\
151 \\
99\end{array}$ & $\begin{array}{l}10 \\
65 \\
99\end{array}$ & $\begin{array}{r}2 \\
21 \\
63\end{array}$ & $\mathrm{P}<0.01$ \\
\hline 腫将 & $\begin{array}{l}\text { 数 } \\
\text { 単 } \\
\text { 多 }\end{array}$ & & $\begin{array}{l}\text { 発 } \\
\text { 発 }\end{array}$ & $\begin{array}{r}12 \\
4\end{array}$ & $\begin{array}{l}170 \\
105\end{array}$ & $\begin{array}{l}79 \\
94\end{array}$ & $\begin{array}{l}52 \\
34\end{array}$ & $\mathrm{P}<0.01$ \\
\hline 形 & $\begin{array}{l}\text { 態 } \\
\text { 乳 } \\
\text { 乳 } \\
\text { 非孚 } \\
\text { 非孚 }\end{array}$ & $\begin{array}{c}\text { 状 } \\
\text { 状 } \\
\text { 頭 状 }\end{array}$ & & $\begin{array}{r}10 \\
1 \\
7 \\
0\end{array}$ & $\begin{array}{r}197 \\
62 \\
3 \\
12\end{array}$ & $\begin{array}{r}44 \\
76 \\
3 \\
51\end{array}$ & $\begin{array}{r}7 \\
28 \\
2 \\
49\end{array}$ & $\begin{array}{c}\mathrm{P}<0.01 \\
\text { (非乳頭状有荠性を除く) }\end{array}$ \\
\hline 部 & $\begin{array}{l}\text { 位 } \\
\text { 頸 } \\
\text { 三 } \\
\text { 後 } \\
\text { 右 } \\
\text { 左 } \\
\text { 頂 } \\
\text { 前 }\end{array}$ & 角 & $\begin{array}{l}\text { 部 } \\
\text { 部 } \\
\text { 壁 } \\
\text { 壁 } \\
\text { 壁 } \\
\text { 部 } \\
\text { 壁 }\end{array}$ & $\begin{array}{l}3 \\
6 \\
2 \\
5 \\
2\end{array}$ & $\begin{array}{r}6 \\
91 \\
49 \\
55 \\
61 \\
12 \\
2\end{array}$ & $\begin{array}{r}3 \\
47 \\
33 \\
48 \\
36 \\
9 \\
6\end{array}$ & $\begin{array}{r}7 \\
18 \\
18 \\
24 \\
19 \\
11 \\
8\end{array}$ & $\begin{array}{l}\text { 前壁に } \mathrm{G}_{2}, \mathrm{G}_{3} \text { が } \\
\text { 多い }(\mathrm{P}<0.01)\end{array}$ \\
\hline
\end{tabular}

主訴よりみると， $\mathrm{G}_{0}, \mathrm{G}_{1}$ では膀胼炎様症状を示すこ とが極めてまれ $(7 / 268=2.6 \%)$ であるのに反し， $\mathrm{G}_{2}$, $\mathrm{G}_{3}$ ではこれを主訴とする場合が $23.4 \%$ ああり，特に $\mathrm{G}_{3}$ では $41.0 \%$ がこの症状を主訴としている（2×4 表, $\chi^{2}$ 検定, $\mathrm{p}<0.01$ で関連性あり). 大きさについて は $\mathrm{G}_{0}, \mathrm{G}_{1}$ では $3 \mathrm{~cm}$ までの腫瘍が過半数であるのに対 し, $\mathrm{G}_{2}, \mathrm{G}_{3}$ では $3 \mathrm{~cm}$ 以上の腫瘍が過半となる $(3 \times 4$ 表, $\chi^{2}$ 検定, $\left.\mathrm{p}<0.01\right)$. 腫瘍数との関係をみると high grade の例で多発腫瘍が多く認められる $\left(4 \times 2\right.$ 表, $\chi^{2}$ 検定, $\mathrm{p}<0.01$ ). 腫瘍の形態は $\mathrm{G}_{0}$ は inverted papilloma を含め, 有茎性腫瘍が大部分であり, 例外的に 1 例の広基性腫瘍がみられるが，大きさは極めて小さな ものであった. $\mathrm{G}_{1}$ では有茎性腫瘍が広基性腫腸に比し 約 3 倍の多くをみるが, $\mathrm{G}_{2}$ ではむしろ広基性腫瘍が多 くなり，さらに $\mathrm{G}_{3}$ になると広基性腫瘍が $89.5 \%$ と圧倒 的に多くなる.非乳頭状有茎性腫瘍を除く腫瘍形態と, $\mathrm{G}_{0} \sim \mathrm{G}_{1}$ の $3 \times 4$ 表による $\chi^{2}$ 検定では $\mathrm{p}<0.01 て ゙$ 関連 性が認められる。発生部位別に悪性度をみた場合, 浸 潤度の場合と同様, 前壁に $\mathrm{G}_{2}, \mathrm{G}_{3}$ の腫場が多く, これ 以外の部位での悪性度の分布と $\chi^{2}$ 検定で $\mathrm{p}<0.01$ と
有意である。

（8）特異な膀胖腫瘍

713例中, 尿膜管に由来したと考兄られる腫瘍は10例 (1.4\%) であり，いずれも腺癌であった。またいわゆ る上皮内癌を含む flat carcinoma は41例 $(5.8 \%)$ を占 める。その他, inverted papilloma 7 例 (1.1\%), 膀 胱䕀室内腫瘍 4 例 $(0.6 \%)$, 非上皮性腫瘍 4 例 $(0.6 \%)$ も比較的特異な膀胱腫瘍と思われる。

（9）治療方法

腫瘍初発時になされた処置は，他施設で行なわれた 内容についても, 紹介状, 問診, 問い合せなどにより 出来るだけ明らかとしたが，1例でその判断が不可能 であった。外科的処置内容は Table 9に示す。生検の みに終った25例を含め68例には手術的治療がなされて おらず,他の645例には何らかの外科的処置がなされて いる。 らち膀脱 (尿道) 全摘術は 173 例 $(24.3 \%)$ 飞施 行され，他は膀胼保存的処置である。 その内容は TUR 259 例 (36.3\%), 部分切除術148例 (20.8\%), TUC 34 例 $(4.8 \%)$, 開放性腫瘍単純切除術（含粘膜刹離術） 30例 (4.2\%) であった。 
Table 9 膀脂腫瘍初発時の外科的処置

\begin{tabular}{|c|c|c|}
\hline 内 容 & 症例数 & $(\%)$ \\
\hline $\begin{array}{l}\text { 施行せず } \\
(ら ち \text { 生検のみ) }\end{array}$ & $\begin{array}{r}68 \\
(25)\end{array}$ & 9.5 \\
\hline 膀胼尿道全摘術 & 31 & 4.3 \\
\hline 膀 胱 全 摘術 & 142 & 19.9 \\
\hline 部 分切除術 & 148 & 20.8 \\
\hline $\begin{array}{l}\text { 腫瘍単純切除術 } \\
\text { (含粘膜䟝離術) }\end{array}$ & 30 & 4.2 \\
\hline TUR & 259 & 36.3 \\
\hline TUC & 34 & 4.8 \\
\hline 不 & 1 & 0.1 \\
\hline 計 & 713 & \\
\hline
\end{tabular}

Table 10 初回治療手段と生存率

\begin{tabular}{|c|c|c|c|c|}
\hline & 症例数 & 3 年 $(\%)$ & 5 年 $(\%)$ & 10 年 (\%) \\
\hline 膀脱尿道全摘術 & 31 & 65.4 & 65.4 & 65.4 \\
\hline 膀 胱 全 摘 術 & 142 & 61.0 & 55.8 & 41.7 \\
\hline 部 分 切 除 術 & 144 & 67.2 & 58.1 & 41.3 \\
\hline 腫瘍単純切除術 & 29 & 89.7 & 79.2 & 68.1 \\
\hline TUR & 259 & 90.2 & 86.4 & 76.7 \\
\hline TUC & 34 & 87.9 & 74.3 & 55.3 \\
\hline 生 検 の み & 25 & 13.5 & 13.5 & 0 \\
\hline 外科的処置なし & 43 & 18.7 & 13.4 & 13.4 \\
\hline 計 & 713 & 71.3 & 64.9 & 50.4 \\
\hline 全例の期待生存率 & & 94.7 & 90.3 & 77.9 \\
\hline
\end{tabular}

Fig. 2 初回治療手段と生存率

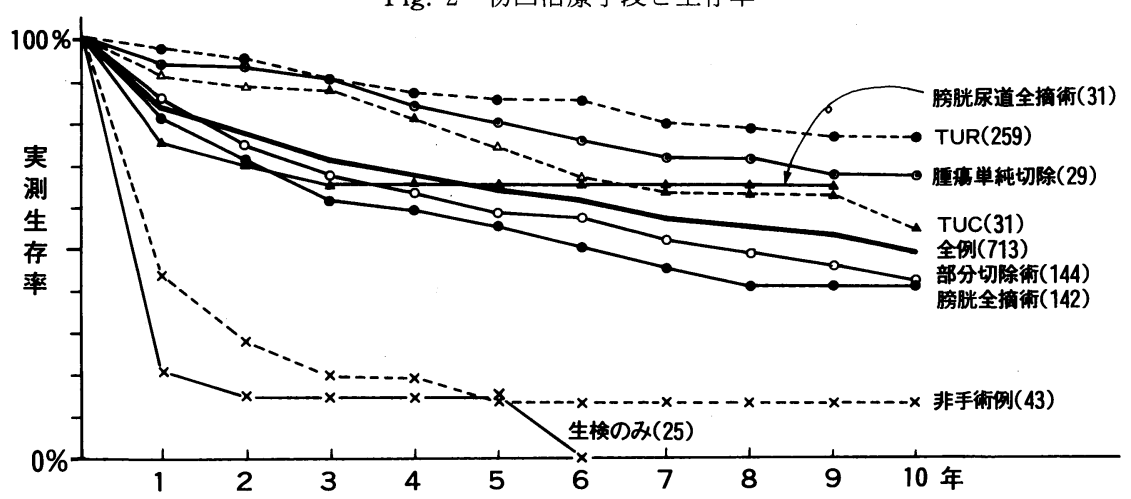

放射線照射は58例に行なわれているが，原発巣の治 療を目的としたもの 25 例，術前照射としてなされたも の 8 例, 膀胱内再発を予防する意目で施行されたもの 20例が主な目的であり，その他転移巣に対する治療 3 例, 膀胱全摘後の骨盤腔内での腫瘍再発を予防する目 的で行なわれたもの 2 例がみられた。

抗癌剂膀脱内注入療法も83例に施行されている. 治 療目的に注入した例は 6 例と少なく，またらち 2 例は 後に手術的治療に移行している。腔内再発予防を目的 としたものが72例と最も多く, 治療括よび予防のいず れの目的も合せた注入も 5 例に施行された。

全身性抗癌化学療法も44例に用いられている。この らち12例は膀胱腫瘍の治療を目的としたものであり， 1 例は術前処置として適用された。また他の31例はい ずれも腔内再発をたは遠隔転移の発生を予防する意図 をもって施行された。

（10）膀胼腫瘍初発後の生存率

腫瘍初発後の症例の生命に関する経過は, 腫瘍の性 質と治療方法のいずにも大きく影響され，また治療手
段も膀脱保存的処置がかなりの頻度を占めるため, そ の合理的な検討は必ずしも容易ではない。むしろ各々 の処置方法別に対象となった腫瘍の性状を分析しつつ 検討する必要がある. しかし本稿の目的に沿い, ここ では初回の外科的処置と最終的な生命表法による生存 率を Table 10, Fig. 2に示すにとどめた.な招713例全 例の 3 年, 5 年, 10 年の実測生存率は $71.3 \%, 64.9 \%$, $50.4 \%$ であり, これらの期待生存率は各々 $94.7 \%$, $90.3 \%, 77.9 \%$ であるため, 膀胱腫瘍全例での相対生 存率は 3 年 $75.3 \%, 5$ 年 $71.9 \%, 10$ 年 $64.7 \%$ となる(含 手術死).

(11）膀脱保存処置後の腔内再発

膀脱を保存した手術的治療後の膀胼内再発の状態 を, 第 1 回目の再発を対象とし, 生命表法に準じて算 出した結果を Fig. 3に示す. 腔内再発予防処置の有無 を問わず, 全例での再発率は 3 年 $50.9 \%, 5$ 年 $61.5 \%$, 10 年 $73.9 \%$ となるが, 各治療法別にみると, 部分切除 術では $51.0 \%, 61.4 \%, 77.3 \%$, 開放性腫瘍単純切除 術(含粘膜剝離術)では34.3\%, 40.2\%, 64.1\%, TUR 
Fig. 3 膀胼保存手術後の腔内再発

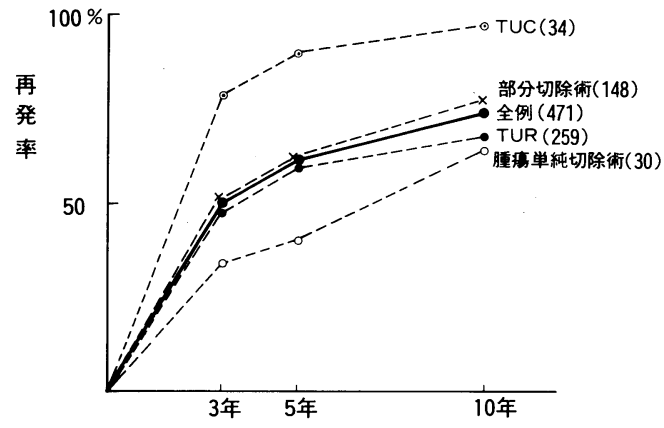

では $48.8 \%, 60.0 \%, 67.9 \%$, TUCでは $79.2 \%$, $89.6 \% ， 96.5 \%$ となり，特に TUC での再発率が高く， またこれは TUR と比較すると全期間を通じ， $Z$ 検定 により， $\mathrm{p}<0.05$ 又は $\mathrm{p}<0.01$ の危険率で有意であっ た.

\section{考 察}

昭和 32 年, 当科が皮虐泌尿器科より分離独立して以 来, 昭和59年 3 月までに 713 例の膀脱腫瘍症例の診療を 行なったが，今回これら症例の腫瘍初発時の臨床像を 中心に分析を行なった。

その結果は, 市川(5)による全国集計, 吉田 ${ }^{677)}$, 岡島ら ${ }^{8)}$ による立派な臨床的研究と文献的考察をはじとする本 邦諸家のこれまでの報告9) 32) と本質的な差異はない と思われるが，以下多少の考察を行なってみたい。な 打欧米文献との比較検討は最近の報告 ${ }^{29330)}$ 亿扔いて既 によくなされて扣り，重複を避けた。

膀胼腫瘍症例の年齢分布, 性比については, 最も好 発するのは60歳台であるとの報告が大部分であり, 今 回の結果もこれによく一致する。しかし平均年龄でみ ると男子 61 62歳前後, 女子ではこれより $1 \sim 2$ 歳若 年であるとする報告が多( ${ }^{14221299}$ に反し，今回の集計 では女子平均年齢は男子例に比し有意に高齢であるこ

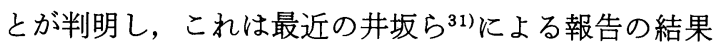
とよく一致していた。過去の報告の一部には, 初発腫 瘍と再発腫瘍との区別が必ずしも明確でない場合もあ り，これがこの様な差異を示した一因かと思われる。 な扢この点はさらに発見の糸口（症状）, 腫瘍の性状, 生存率，再発率などの分析結果にもかなりの影響をも たらすものと考兄られ，注意が必要である，性比につ いては，過去2.6 6.2：1 と男子に多く発生するとの 結果が示されている(6) 32)が，今回の結果はこれらの報 告のほ添中間的な値となっている。

職業性と思われる腫瘍の占める割合は, 当科では 16
名 (2.2\%) であったが，この比率は診療施設の所在地 や性格にも大きく影響を受けるものと思われる，職業 性腫瘍の特異な性格については稿を改めて詳述した い.

自覚症の分析結果も過去の報告と大差はな く8)991115)19)22) 24227) 29(32), また特に頻尿, 排尿痛を伴な 丂腫瘍では, 無症候性血尿例に比し, ょり進展した悪 性度の高い腫瘍が多いことは, 多少異論もあるが12119), すでに明らかとされて括り7)816)30), 今回の結果も新た な知見ではないが，それを再確認出来たものと考兄る。

内視鏡所見では, 腫瘍数からみて単発性, 多発性の 割合が, 単発性が過半数をやや越えるといら過去の報 告8)911112)15)19922(24)25)27299)30322) 極めてよく一致するが, 大きさについては $3 \mathrm{~cm}$ 以上，あるいはほぼこれに相当 するサイズ以上が全体の $30 \%$ 前後であるとする報告が 多(15)23)24)27)32)のに比し, 今回の結果では大きな腫瘍 がやや多くみられたとしてょいであろう。この理由も 前に述べた初発腫浧に限定したことが影響していると 思われる。形態は乳頭状有茎性腫瘍が全体の $32.2 \%$ 〜 48.6\%を占めるとされるが15)1922222729)32), 当科の結 果も $44 \%$ とこれによく一致した。腫崵の存在部位につ いては，両側壁に最も多く1112121522224)32), 次いで, 後壁 又は三角部があげられている。しかし報告により差異 の著しいのが三角部での発生頻度であり, $4.4 \%$ とい 数値をはじめとして非常に低い頻度を報告しているも のと 2228229), 33.7\%を頂点として非常に高い頻度を述 べている報告812121424)27) に分かれる，この理由は，腫瘍 が実際によくみられる尿管口周囲をどの様に取り扱う かにかかっていると思われる。高士ら ${ }^{30}$ は, 尿管口周囲 領域といら部位を設定して検討し，全例中の実に $41 \%$ がこれにみられたとしている，現在の規約にはこの様 な取り扱いはなされていないが，臨床的には有意義・ 実際的な区分設定と思われる。な打今回の報告での三 角部の頻度 $26.7 \%$ は尿管口周囲を含んだものである.

病理組織所見については, 組織型として圧倒的に多 いのが移行上皮性腫瘍であることはよく知られてい

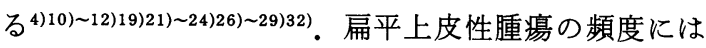
多少の差があり，比較的高い数值を述べている報告が 一部にみられるが5)910)，判断基準の問題かと思われ， 通常は非常に低い数値が報告されている。楾癌の 占める頻度は尿膜管腫瑒を含めるか否かによりかなり 左右されるが，例光本報告の様に含めたとしても $3.1 \%$ 程度であり，非常にまれなものと考えてよい，悪性度 の分布については，過去の報告の多くが Broders の分 
類を採用して括り，今回の結果と単純な比較は困難で あるが，一般的には規約に和ける $\mathrm{G}_{0}$ 又は $\mathrm{G}_{3}$ に相当 するもの，特に前者の割合が比較的低く ${ }^{18) 27 / 29) 30)}, G_{1}$, $\mathrm{G}_{2}$ に相当するものの割合が多いかと思われ

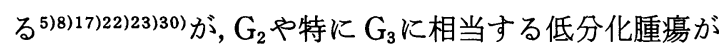
多いとの報告もみられる ${ }^{1121227) 29)}$. 腫場の進展度につ いては, $\mathrm{T}_{2}$ 以下の腫瘍が 60 ～ $80 \%$ を占める点で大部分 の報告が一致している(11)2123) 25)30). また進展度は悪性 度と非常に良い相関がみられることもよく知られた事 実である ${ }^{15) 22(23) 29) 30) . ~}$

これら病理組織所見と腫瘍の性状についても種々検 討されている.内視鏡的形態と悪性度，または進展度 の間には一般に相関関係が指適されてお $\eta^{15191922) 30332)}$, 本報告の結果もこれに一致する。ただし 非乳頭状有茎性腫瘍は一定の傾向を示し難いと思われ る. 発生部位との関連は多少意見が分かれて招り，頂 部や前壁に，時には䅡部に high grade, high stage の 腫瘍が多いとする意見 ${ }^{8) 15)}$ と, 部位別の悪性度・進展度

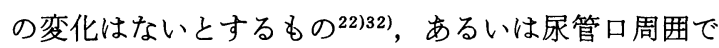
low grade, low stage が多いとする意見 ${ }^{30}$ などがあ る。今回の結果では，前壁において他部位に比し有意 に high grade, high stage の腫場が多くみられたこと 以外は特に部位と悪性度・進展度との関連はないと結 論された。 悪性度, 進展度と腫瘍の大小については有 意の相関関係がみられることも既に報告されて招 $\eta^{22) 32)}$ また腫崵の数之の関係は今回の集計では多発 例に high grade, high stage の腫湟が多いことの結論 を得たが，過去の報告では特に関係がないとの意 見22)3032)や，本報告と同様の結論を述べているも

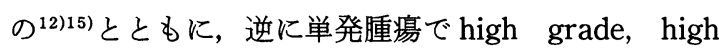
stage の腫場が多いとの報告もみられている30).

腫瘍初発時になされた治療の内容についてはTable 9に示したと招りであるが, 前述した様にこれら全てが 当科に招いてなされたものではなく，95例は他施設に おいて施行されたものである。このため，ここにあげ た数值は当科での基本的な治療方針と必ずしも一致し ない。

以下，治療法の選択に当り，当科が採用してきた基 本的方針について多少述べて拈きたい，昭和 32 年の開 設後約 3 年間, 治療の主流は膀胱部分切除々開放性腫 瘍単純切除または粘膜剥離術であり, Table 9 に示し たこれら手術の大半はこの時期になされてたものであ る. しかし膀脱全摘除術も昭和 32 年 2 月に開始され, , 当初より積極的に取り入れられていた。をた昭和 34 年
から TUR が導入され, 昭和 42 年頃までは表在性腫瘍 には TUR 又は開放性腫瘍単純切除, 浸潤性腫崵に対 しては部分切除術又は全摘除術といら選択がなされて きた。しかし TURの技術的向上による適応拡大扣よ び部分切除術に関する分析検討より, 昭和 42 年頃から は表在性腫湟にはTUR, 浸潤性腫瘍には全摘除術と いら基本方針が出され，以後約 17 年間，現在に至るま でこの方針が継承されてきた。なお，膀胱全摘除術に おいては一部例外を除き完全なりンパ節廓清は併用さ れておらず，また採用された尿路変更術は，Table 12 には示されていないが, 回腸導管148例, 尿管皮膚瘻 47 例, 直腸膀脱 2 例, 腎瘦 2 例, 結腸導管 1 例, 尿管 $\mathrm{S}$ 状結腸吻合術 1 例, その他 1 例である。な抗これら数 值および以下の補助的処置の数はあくまで初発腫瘍に 対してのものであり, 再発性腫瘍に対する処置は含ま れていないことをさらに強調しておきたい。

放射線療法や抗癌剂膀胱内注入療法は基本的にはや むを得ないと思われる症例に対してのみ施行されたも のであり, また水圧療法や温熱療法は当科では過去 1 例の治療経験もない。

Table 10には初回治療別に症例の生存率を示した が,これはあくまでも参考のための数值であり，これ ら治療法の可否を論じるべきデータではない.ただし， すでに二次的に施行された症例も含め, 膀胼全摘除術 症例の大半は大阪府立成人病センタ一症例ともに黒 田 ${ }^{33}$ により分析検討され既に報告されている，部分切 除, TUR などの各々の処置とその結果や問題点につ いては, 補助的療法の意義も含め今後更に詳細に検討 し報告する予定である。

膀脱保存処置後の腔内再発については既に23 70\% の数值が挙げられている2025)322が，今回の集計では他 の一般的な報告に比しやや高い頻度かと思われる。算 出方法や観察期間の相異がこれに最も強く影響するも のと思われるが, 高安ら ${ }^{20)}$ もいらよ5に再発率の算出 方法自身にも考光てみる余地があろう。この再発の問 題についても, 予防的処置の有効性とともに今後報告 する予定である。

以上, 今回の結果につき本邦文献とともに多少の考 察を行なってみたが, 過去かなり長い期間の症例であ るため, ここに示したデータが現在の医療水準よりみ て妥当か否かには多少疑問なしとはいえない。しかし 逆に，長期間の経過镜察が可能であったことから，生 存率や再発率に和ける数値の信頼性もある程度向上し たのではないかと考觉ている、本報告を基礎とし，今 
後前述した問題などにつき分析を加え報告する予定で ある。

\section{結 語}

昭和 32 年 1 月より昭和 59 年 3 月までの期間に大阪大 学医学部附属病院泌尿器科を受診した膀胼腫瘍713例 につき，その腫瘍初発時の臨床像, 膀胼鏡所見, 臨床 的・病理組織学的診断, 初回治療後の生存率拈よび膀 胼保存処置後の再発率につき検討，これとともに当科 に扣ける過去の膀胱腫瘍に対する処置方法の実状を述 べるとともに，これまでの主な本邦文献と比較考察を 行なった。

\section{文献}

1）大野良之, 青木国男, 黒石哲生, 富永裕民：日本人 の尿路性器癌の疫学. 臨泌，38，555-569，1984.

2) 日本泌尿器科学会, 日本病理学会編：泌尿器科・病 理膀胖癌取り扱い規約. 第 1 版, 金原出版, 東京, 1980.

3）開原成允：東大コンピョータ医㞠研究会：医用、 イコンシリーズ（3)，マイコンによる医療統計処 理。中山書店, 東京, 1983 。

4）伊東信行：膀胱腫瘍の組織分類. 臨泌，37, 101-107, 1983.

5）市原篤二：膀胱腫县の遠隔成績調査. 日泌尿会誌, 49, 602-610, 1958.

6）吉田 修：膀胀癌に関する研究. 第 1 編, 日本膀胱 癌の統計的拉よび疫学的研究. 泌尿紀要, 12, 1040 $-1064,1966$.

7）吉田 修：膀胱癌に関する研究. 第 2 編, 膀胱癌患 者244例の臨床的観察（浸潤度および遠隔成績を中 心として一。泌尿紀要，12，1261-1280，1966.

8）岡島英五郎, 平松 㑆, 本宮善恢, 入矢一之, 林威 三雄, 石川昌義：膀胼腫場に関する臨床的研究. 第 1 報, 膀胼腫瘍の臨床統計的観察. 日泌尿会誌, 61 , 783-804, 1970 .

9）加藤篤二, 石部知行, 田辺泰民, 竹中生昌, 福重 満, 白石恒雄, 平川十春, 数田 稔, 藤本洋治, 溝 口勝, 嶋田孝宏, 田中広見, 小川昌彦, 梶尾克彦, 伊藤順勉：膀胼腫場の手術成績。泌尿紀要， 12, 333-340, 1966.

10）沼里 進, 高橋崎三, 佐々木秀平, 伊藤幸夫, 小原 紀彰, 岩動 孝, 長根 裕, 吉田郁彦, 山田行夫, 村本俊一, 半田紘一, 久保 隆, 大堀 勉: 膀胼庫 瘍一治療と遠隔成績。泌尿紀要, 18，345-352, 1972.

11）黑沢昌也, 鈴木騏一, 佐々木健二, 杉田篤生, 加藤 正和：膀胀腫場の臨床統計的観察. 日泌尿会誌, 63, 1001-1006, 1972.

12）鈴木茂章, 島谷政佑, 寺尾暎治：膀胼腯瘍の臨床統 計. 第 1 報, 発生頻度, 膀胼鏡所見, 組織学的所見
について。泌尿紀要，19，413-423，1973.

13）三浦柝也, 堀内誠三，中川完二, 親松常男, 平石政 治, 土屋文雄, 豊田 泰: 膀胖腫崵の治療成績. 日 泌尿会誌，64，95-104，1973.

14）相模浩二, 林 睦雄, 暒尾克彦: 国立福山病院に拉 ける 5 年間 (1969-1973) の尿路悪性腫劰統計。泌 尿紀要，21，303-307，1975.

15）西尾正一, 柏原 昇, 川喜多順二, 西島高明, 前田 勉, 松村俊宏, 佐々木進, 船井勝七, 中西純造, 早 原信行, 辻田正昭, 岸本武利, 前川正信：膀胱癌の 臨床統計学的研究. 泌尿紀要, 22, 489-495, 1976.

16）伊藤秦二, 森 義則, 永田 肇, 清原久和：膀胼腫 瘍270例の治療成績。TURを中心として，泌尿紀 要, 22, 33-41, 1976 .

17）新島端夫，松村陽右，片山泰弘，森永 修，池 紀 征, 朝田俊彦, 尾崎雄次郎, 白石哲朗：膀胖腫煌の 臨床統計的研究. 第 1 報, 治療法と予後を中心とし て. 日泌尿会誌，67，1057-1063，1976。

18）井原義雄, 大塚 久, 赤木 郷：膀胱移行上皮癌の 病理組織学的悪性度に関する研究. 最新医学, 32, 2216-2227, 1977.

19）浜野耕一郎，栃木宏水，森下文夫，堀内英輔，鈴木 紀元, 波部英夫, 加藤広海, 朴木繁博, 山崎義久, 斉藤 薫, 森 幸夫, 多田 茂: 膀胱腫瑒の臨床的 観察. 泌尿紀要, 22，463-473，1977.

20）高安久雄, 小川秋実, 北川龍一, 柿沢至恕, 岸 洋 一, 赤座英之, 石田仁男 : 膀脂腫場の治療成績. 日 泌尿会誌，69，669-678，1978.

21）吉田 修, 林正健二：膀胼癌の遠隔成績. 最新医 学, 34, 823-826, 1979.

22）深津英捷, 瀬川昭夫, 千田八郎, 早瀬喜正, 西川源 一郎：膀脱腫暘に関する臨床研究. 第 1 報, 膀胱腫 湟の臨床統計的観察。泌尿紀要, 26, 9-18, 1980.

23）新村研二, 木村茂三, 早川正道, 藤岡俊夫 : 膀脂腫 瘍の臨床統計的観察. 泌尿紀要, 26, 657-662, 1980.

24）井川幹夫, 相模浩二, 平山多秋：膀胱腫場の臨床統 計的観察. 西日泌尿, 44, 747-754, 1982.

25）小松原秀一, 安藤 徹, 佐藤昭太郎：膀胱腫瑒の治 療一15年間の臨床統計的観察から一, 新潟大学泌 尿器科入院患者統計 (昭和 38 年一昭和 52 年). 第 8 報。西日泌尿，44，31-39，1982。

26）松浦 健, 杉山高秀, 辻橋広典, 加藤良成, 朴 英 哲, 国方聖司, 神田英憲, 片岡喜代徳, 永井信夫, 金子茂男, 郡健二郎, 井口正典, 秋山隆弘, 八竹 直, 栗田 孝：膀胀腫瘍の臨床的検討. 泌尿紀要, 29, 23-30, 1983.

27）磯松幸成，鏑木 豊，真下 透，三木正也，神保 進, 鈴木孝憲, 今井強一, 山中英寿：膀胼腫瘍の臨 床統計的観察。西日泌尿，45，1209-1212，1983.

28）柳下次雄，広瀬 毫，松本英覀，中山孝一，松島正

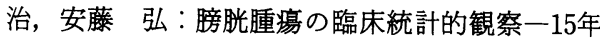


間の治療成績を中心として一。泌尿紀要，29， $823-829,1983$.

29）佐々木秀平, 久保 隆, 大塚 勉, 小池博之, 里舘 良一: 原発性膀胱癌181例の臨床病理学的研究. 日 泌尿会誌, 75, 391-403，1984。

30）高士宗久, 村瀬達良, 傍島 健, 伊藤 博, 青田泰 博, 安藤 正, 下地敏雄, 三宅弘治, 三矢英輔：膀 胼腫瘍の統計的研究一臨床的 - 病理学的因子の考 察一。日泌尿会誌, 75, 1452-1460, 1984.

31）井坂茂夫, 五十嵐辰男, 秋本 普, 岡野達弥, 島崎
疜, 松駦 理 : 高齢者膀胱癌の治療成績. 泌尿紀 要, 30, 1793-1799, 1984.

32）小倉裕幸, 新里 滋, 高田 耕, 吉田郁彦, 山本利 樹, 篠村五雄：最近10年間における膀胱腫瘍の臨 床統計，西日泌尿，46，83-90，1984.

33）黑田昌男：膀胱癌の臨床病理学的研究一浸潤性膀 胼癌の予後規制因子の検討一. 日泌尿会誌，75, 379-390, 1984.

（1985年 4 月 6 日受付） 